\title{
Zinc accumulation, photosynthetic gas exchange, and chlorophyll $a$ fluorescence in Zn-stressed Miscanthus $\times$ giganteus plants
}

\author{
G. ANDREJIĆ, ,\#, G. GAJIĆ ${ }^{* *}$, M. PRICA*, Ž. DŽELETOVIĆ\# ${ }^{\#}$ and T. RAKIĆ ${ }^{*,+}$ \\ Department of Plant Ecology and Phytogeography, Faculty of Biology, University of Belgrade, 11000 Belgrade, Serbia* \\ Department of Ecology, Institute for Biological Research "Siniša Stanković", University of Belgrade, \\ 11060 Belgrade, Serbia ${ }^{* *}$ \\ Institute for the Application of Nuclear Energy, University of Belgrade, 11080 Zemun, Serbia ${ }^{\#}$
}

\begin{abstract}
Accumulation and distribution of zinc within Miscanthus $\times$ giganteus plants grown on elevated $\mathrm{Zn}$ concentrations and their photosynthetic performance were investigated. High concentrations of $\mathrm{Zn}$ in soils caused an increase of its concentrations in all plant organs. The bioconcentration factor, bioaccumulation factor, and translocation factor were lower than one indicating that $M . \times$ giganteus is an excluder plant species. Excessive $\mathrm{Zn}$ induced visible leaf damage, i.e. chlorosis and necrosis, only in the oldest leaves, pointing to $\mathrm{Zn}$ accumulation. Elevated amounts of $\mathrm{Zn}$ in leaves significantly lowered the photosynthetic rate, transpiration rate, stomatal conductance, intercellular $\mathrm{CO}_{2}$ concentrations, parameters of chlorophyll $a$ fluorescence, and chlorophyll $b$ content. Despite $\mathrm{Zn}$ excess in leaves, there was no severe reduction in the maximal quantum yield of PSII photochemistry, indicating a high photosynthetic capacity, high tolerance to elevated $\mathrm{Zn}$ concetrations, and ability of $M . \times$ giganteus to grow on $\mathrm{Zn}$-contaminated soils.
\end{abstract}

Additional keywords: pigments; photosynthesis; phytoremediation; Zn tolerance.

\section{Introduction}

Zinc is a ubiquitous chemical element, the average content of which in the Earth's crust is $70 \mathrm{mg} \mathrm{kg}^{-1}$ (Kabata-Pendias 2011), whereas its concentration in world soils can vary between 10 and $100 \mathrm{mg} \mathrm{kg}^{-1}$ (Martens and Smolders 2013). The availability of $\mathrm{Zn}$ for plant uptake depends on its concentration in the soil, the soil clay fraction, and $\mathrm{pH}$ of the soil. Zinc is slightly mobile and poorly available at alkaline $\mathrm{pH}$ and in soils with a high clay fraction due to strong Zn binding (Kabata-Pendias 2011, Rutkowska et al. 2013, Gajić et al. 2016). Excessive concentrations of $\mathrm{Zn}$ in soils naturally result from the chemical and physical weathering of parent rocks rich in $\mathrm{Zn}$. High concentrations of $\mathrm{Zn}$ in soil frequently derive from anthropogenic input through mining and smelting operations, treatment of agricultural soils with $\mathrm{Zn}$ fertilizers, and combustion of fossil fuels in urban environments (Pilgrim and Hughes 1994, Kabata-Pendias 2011, Martens and Smolders 2013).
Zinc is an essential element for plants and acts as a catalytic or structural cofactor of a large number of enzymes and regulatory proteins, and it is involved in metabolism of carbohydrates, proteins, and phosphates (Marschner 1995, Kabata-Pendias 2011). High concentrations of $\mathrm{Zn}$ can damage cell functioning due to the displacement of other elements having similar diameter and charge, and they can also disrupt a number of essential processes in the plant organism. Thus, $\mathrm{Zn}$ excess reduces plant growth and induces chlorosis of leaves, which can be a result of $\mathrm{Zn}$-induced $\mathrm{Fe}$ or $\mathrm{Mg}$ deficiency (Marschner 1995, Sagardoy et al. 2009). Moreover, it decreases leaf water content, transpiration rates, stomatal conductance, the net photosynthetic rate, and photosynthetic efficiency (Bonnet et al. 2000, Sagardoy et al. 2009). Although the toxicity thresholds for $\mathrm{Zn}$ widely depend on the plant species, they can also be highly variable between

Received 31 August 2017, accepted 10 January 2018, published as online-first 21 June 2018.

${ }^{+}$Corresponding author; e-mail: tamaraz@bio.bg.ac.rs

Abbreviations: $\mathrm{BAF}$ - bioaccumulation factor; $\mathrm{BCF}$ - bioconcentration factor; Car - carotenoids; Chl - chlorophyll; $C_{\mathrm{i}}-$ intercellular $\mathrm{CO}_{2}$ concentration; $\mathrm{DM}$ - dry mass; $E$ - transpiration rate; $\mathrm{F}_{0}$ - minimal fluorescence yield of the dark-adapted state; $\mathrm{F}_{\mathrm{m}}-$ maximal fluorescence yield of the dark-adapted state; $F_{v}$ - variable fluorescence; $F_{v} / F_{m}$ - maximal quantum yield of PSII photochemistry; $g_{\mathrm{s}}$ - stomatal conductance; $P_{\mathrm{N}}$ - photosynthetic rate; $R$ - respiration; TF - translocation factor.

Acknowledgements: The authors gratefully acknowledge financial support from the Serbian Ministry of Education, Science, and Technological Development (grant No. 173030 and grant No. 173018). We thank the reviewers and the editors for their valuable suggestions and comments. We would also like to thank Mr. Raymond Dooley for editing the English language of the manuscript. 
different growth stages of the same species. Toxicity symptoms in sensitive plants become usually visible at 150-200 mg(Zn) kg-1(dry mass, DM) (Kloke et al. 1983). Most commonly, the toxic $\mathrm{Zn}$ concentrations in various plants range from 100 to $500 \mathrm{mg}(\mathrm{Zn}) \mathrm{kg}^{-1}(\mathrm{DM})$, and toxic effects are manifested as stunted plant growth and leaf chlorosis (Marschner 1995).

Miscanthus $\times$ giganteus (Greef \& Deuter) (Poaceae) is a perennial and rhizomatous $\mathrm{C}_{4}$ plant that produces high biomass under temperate climatic conditions (Naidu and Long 2004). It is undemanding in regard to nutrient supply, is able to grow on a wide range of soils, and grows with minimal costs in one location for a long period of time (15-20 years), due to which its cultivation is highly economical (Zub and Brancourt-Hulmel 2010, Dželetović et al. 2013, McCalmont et al. 2017). It is cultivated as a renewable energy source, but its production is restricted to marginal lands. Studies focused on the phytoremediation potential of $M . \times$ giganteus show its potential to grow on soils contaminated by heavy metals or organic pollutants (Técher et al. 2012, Wanat et al. 2013, Nsanganwimana et al. 2014, Pavel et al. 2014, Pidlisnyuk et al. 2014, Bang et al. 2015, Figala et al. 2015, Pelfrêne et al. 2015, Pandey et al. 2016).

\section{Materials and methods}

Plant material and growing conditions: The rhizomes of $M$. $\times$ giganteus used in this experiment were collected from the field at the Institute for Application of Nuclear Energy (INEP), Zemun, Serbia (445 $\left.51^{\prime} \mathrm{N}, 20^{\circ} 22^{\prime} \mathrm{E}\right)$, where plants have grown for years. Rhizomes with several auxiliary buds were cut from dormant mother plants and planted in pots under greenhouse conditions in March 2016. The pot experiment was conducted in facilities of the INEP in Zemun, Serbia. Two plant rhizomes $(7-10 \mathrm{~cm}$ long) with several buds were planted per each 10-L pot in soil with a depth of $10 \mathrm{~cm}$. Plants were grown for one month (March) in unpolluted soil under greenhouse conditions (natural light conditions, minimum-meanmaximum daily temperature of $10.1-13.3-16^{\circ} \mathrm{C}$, respectively). After the first month of growth, plants were subjected to single treatment with different concentrations of $\mathrm{ZnSO}_{4} \times 7 \mathrm{H}_{2} \mathrm{O}$ :

\begin{tabular}{ll}
\hline Treatment & {$\left[\mathrm{mg}(\mathrm{Zn}) \mathrm{kg}^{-1}(\mathrm{DM})\right]$} \\
\hline Control & 0 \\
$\mathrm{~T}_{250}$ & 250 \\
$\mathrm{~T}_{500}$ & 500 \\
$\mathrm{~T}_{1,000}$ & 1,000 \\
\hline
\end{tabular}

Plants in pots were then transferred to the field. In the course of the next three months, all plants were exposed to natural light conditions (direct sunlight: April - $200.8 \mathrm{~h}$, May - 225.9 h, June - 269.7 h), min-mean-max daily temperatures of $10-15.5-21^{\circ} \mathrm{C}$ in April, $12.6-17.5-22.6^{\circ} \mathrm{C}$
There is a significant body of published data related to the physiological and biochemical response of Miscanthus to low temperatures (Beale et al. 1996, Głowacka et al. 2015, Fonteyne et al. 2016, Jiao et al. 2016, 2017), the effect of different light intensity (Sun et al. 2012, 2014; Ubierna et al. 2013, Ma et al. 2017), water deficit (CliftonBrown et al. 2002, Ings et al. 2013), influence of the bacterial community (Técher et al. 2012), the effect of arbuscular mycorrhizal fungal inoculation (Firmin et al. 2015), and usefulness of fertilizers (Ma et al. 2017, Pogrzeba et al. 2017). However, aspects of the photosynthetic response of Miscanthus to contamination by different metals still remain far from being completely understood.

High leaf concentrations of Zn may adversely affect the amount of pigments, gas exchange, and photosynthetic activity in this plant species. Accordingly, the aims of this study were as follows: (1) determination of $\mathrm{Zn}$ concentrations in the soil and in plant organs in order to assess the phytoremediation potential of $M . \times$ giganteus; and (2) assessment of the effects of different leaf concentrations of $\mathrm{Zn}$ on the pigment content and various photosynthetic parameters.

in May, and $17.9-22.5-27.6^{\circ} \mathrm{C}$ in June and were regularly watered with distilled water. The mean relative air humidity was 57, 63 and 66\% in April, May, and June, respectively. During the rare rainy days/nights, the plant soil was protected from rain by an elastic plastic cover mounted on the pot, thinly wrapping the plant stem and being detached $15 \mathrm{~cm}$ from the soil surface. Otherwise, the pots were not covered. The experiment was carried out in five replicates per each treatment in a complete randomized block design.

The soil used in this study was collected from a depth of $15-20 \mathrm{~cm}$ at an experimental site of the INEP. The collected soil was air-dried and sieved (diameter $<200 \mu \mathrm{m})$, and then placed in $10-\mathrm{L}$ plastic pots $(5 \mathrm{~kg}$ of soil per each pot). The soil samples were analysed for $\mathrm{pH}$, organic carbon $(\mathrm{C})$, total nitrogen $(\mathrm{N})$, available forms of phosphorus $\left(\mathrm{P}_{2} \mathrm{O}_{5}\right)$, and potassium $\left(\mathrm{K}_{2} \mathrm{O}\right)$, and total content of different elements (Cd, Co, Cr, Cu, Fe, Mn, and Ni). For $\mathrm{pH}$ determination, $25 \mathrm{ml}$ of double distilled water $\left(\mathrm{pH}_{\mathrm{H} 2 \mathrm{O}}\right)$ or $25 \mathrm{ml} 1 \mathrm{M} \mathrm{KCl}\left(\mathrm{pH}_{\mathrm{KCl}}\right)$ was added to $10 \mathrm{~g}$ of soil and stirred for $30 \mathrm{~min}$, after which the $\mathrm{pH}$ value was measured directly in the suspension (Iskra MA 5730). Organic carbon was measured by the method of Tjurin (1965). Total nitrogen content was determined by Kjeldahl digestion (Bremner 1996), and available forms of phosphorus and potassium were analysed using the standard AL-method (Egner et al. 1960). The total element content in soil was determined according to method 3051 (USEPA 1998). The soil characteristics were as follows: $\mathrm{pH}_{\mathrm{H} 2 \mathrm{O}} 6.5$; $\mathrm{pH}_{\mathrm{KCl}} \quad 5.4 ; 1.86 \%$ (organic $\mathrm{C}$ ); $0.072 \%$ (total $\mathrm{N}$ ); 
$18.34 \mathrm{mg}\left(\right.$ available P) $100 \mathrm{~g}^{-1}(\mathrm{DM}) ; 17.97 \mathrm{mg}$ (available K) $100 \mathrm{~g}^{-1}(\mathrm{DM}) ; 0.14 \mathrm{mg}$ (total Cd) $\mathrm{kg}^{-1}(\mathrm{DM}) ; 7.45 \mathrm{mg}$ (total Co) $\mathrm{kg}^{-1}(\mathrm{DM}) ; 38.70 \mathrm{mg}$ (total Cr) $\mathrm{kg}^{-1}$ (DM); 6.91 $\mathrm{mg}($ total $\mathrm{Cu}) \mathrm{kg}^{-1}(\mathrm{DM}) ; 6614.0 \mathrm{mg}$ (total $\left.\mathrm{Fe}\right) \mathrm{kg}^{-1}(\mathrm{DM})$; $777.3 \mathrm{mg}$ (total $\mathrm{Mn}) \mathrm{kg}^{-1}(\mathrm{DM})$; and $36.50 \mathrm{mg}$ (total $\mathrm{Ni}$ ) $\mathrm{kg}^{-1}(\mathrm{DM})$.

Quantification of $\mathbf{Z n}$ in soil and plants: The soils samples were dried at room temperature $\left(25^{\circ} \mathrm{C}\right)$, sieved, and analysed for $\mathrm{pH}$, total $\mathrm{Zn}$ concentration, and available $\mathrm{Zn}$ concentration for each treatment. Total $\mathrm{Zn}$ content in the soil was determined after digestion of sieved soil samples $(<200 \mu \mathrm{m})$ in $\mathrm{HCl}: \mathrm{HNO}_{3}(3: 1, \mathrm{v} / \mathrm{v})$ according to method USEPA 3051 (1998). In order to determine available $\mathrm{Zn}$ content in the soil, dried and sieved soil was mixed continuously for $2 \mathrm{~h}$ in $1 \mathrm{M}$ ammonium acetate and 0.01 M EDTA mixture ( $\mathrm{pH} 7$ ), then filtered using No. 40 Sartorius filter papers according to Standard NF X 31-120 (Pansu and Gautheyroy 2006). The total and available $\mathrm{Zn}$ concentrations were determined by atomic absorption spectrophotometry (Shimadzu AA-7000, Japan). According to FAO (1983), the experimental soil can be classified as a luvic chernozem.

Plant parts (roots, rhizomes, stems, and leaves) were thoroughly washed in tap and deionized water. Air-dried plant material was ground with a ceramic mortar and pestle and then dried at $105^{\circ} \mathrm{C}$ to a constant mass. Plant material was digested in $\mathrm{HNO}_{3}: \mathrm{H}_{2} \mathrm{O}_{2}(2: 1, \mathrm{v} / \mathrm{v})$ according to method USEPA 3052 (1996), after which the $\mathrm{Zn}$ content in plant parts was determined by atomic absorption spectrophotometry (Shimadzu AA-7000, Japan). For quality control, replicate samples, blanks, and standardized reference materials (Soil 90-0115-0106, Bureau Interprofessionnel d'Etudes Analytiques, BIPEA; apple leaves NIST 1515) were included in all analyses.

The phytostabilization potential of $M . \times$ giganteus for $\mathrm{Zn}$ was estimated from several factors: the bioconcentration factor (BCF), the bioaccumulation factor (BAF), and the translocation factor (TF), according to Baker (1981):

$\mathrm{BCF}=\mathrm{Zn}$ concentration in roots/total $\mathrm{Zn}$ concentration in soil

$\mathrm{BAF}=\mathrm{Zn}$ concentration in leaves/total $\mathrm{Zn}$ concentration in soil

$\mathrm{TF}=\mathrm{Zn}$ concentration in leaves $/ \mathrm{Zn}$ concentration in roots

Pigment extraction and quantification: The amounts of

\section{Results}

Concentrations of $\mathrm{Zn}$ in the soil and plant parts: Table 1 presents the total and available concentrations of $\mathrm{Zn}$ in treated soils $\left(\mathrm{T}_{250}, \mathrm{~T}_{500}\right.$, and $\left.\mathrm{T}_{1,000}\right)$ in relation to the control soil and their respective $\mathrm{pH}$ values. The slightly chlorophyll (Chl) $a, \mathrm{Chl} b$, and total carotenoids (Car) in leaves were determined according to Hiscox and Israelstam (1979). Total Chl and Car were extracted with dimethyl sulfoxide (DMSO), and samples were centrifuged at 3,000 $\times \mathrm{g}$ for $10 \mathrm{~min}$. Absorption of Chl $a, \mathrm{Chl} b$, and Car was determined by UV-Vis spectrophotometry (Shimadzu UV-1800, Japan) at 663, 645, and $480 \mathrm{~nm}$, respectively. Chl and Car contents were calculated using equations according to Arnon (1949) and Wellburn (1994), their amounts expressed as mg per $\mathrm{g}$ of leaf DM.

Gas-exchange and $\mathrm{Chl}$ fluorescence measurements: All parameters were measured using an infrared gas analyser of the CIRAS-2 type (PP Systems, USA) equipped with a Chl fluorescence module (CFM). Measurements of net photosynthetic rate $\left(P_{\mathrm{N}}\right)$, transpiration rate $(E)$, stomatal conductance $\left(g_{\mathrm{s}}\right)$, and intercellular $\mathrm{CO}_{2}$ concentration $\left(C_{\mathrm{i}}\right)$ were performed on the penultimate well developed leaf. Conditions in the leaf chamber were as follows: leaf temperature $25^{\circ} \mathrm{C}$, relative air humidity of $60 \%, 370$ $\mu \mathrm{mol}\left(\mathrm{CO}_{2}\right) \mathrm{mol}^{-1}$. Light-response curves $\left(P_{\mathrm{N}} / \mathrm{PPFD}\right)$ were obtained at descending values of PPFD ranging from 2,000 to $0 \mu \mathrm{mol} \mathrm{m} \mathrm{m}^{-2} \mathrm{~s}^{-1}$. The $P_{\mathrm{N}}$ as a function of increasing intercellular $\mathrm{CO}_{2}$ concentrations $\left(P_{\mathrm{N}}\right.$ responses to high $\left.C_{\mathrm{i}}\right)$ was obtained at PPFD of $1,500 \mu \mathrm{mol} \mathrm{m} \mathrm{m}^{-2}$ and $\mathrm{CO}_{2}$ concentrations of $370,750,1,000 ; 1,500$; and 2,000 $\mu \mathrm{mol}\left(\mathrm{CO}_{2}\right) \mathrm{mol}^{-1}$ in the leaf chamber. Measurements were performed during the midmorning period under laboratory conditions at $21^{\circ} \mathrm{C}$ and low ambient irradiance.

For measurement of Chl $a$ fluorescence, a leaf (predarkened for $30 \mathrm{~min}$ ) was enclosed in a $P L C(U)$ universal automatic cuvette (PP-Systems, USA) and the minimal level of fluorescence in the dark $\left(\mathrm{F}_{0}\right)$ was measured after $10 \mathrm{~min}$ of stabilization. Leaf was then exposed to a saturating pulse of actinic light [5,100 $\mu$ mol(photon) $\mathrm{m}^{-2} \mathrm{~s}^{-1}$, duration $700 \mathrm{~ms}$ ] and the maximal fluorescence yield $\left(F_{m}\right)$ was obtained. Values of $F_{0}$ and $F_{m}$ were used to calculate the maximum quantum efficiency of PSII photochemistry $\left(\mathrm{F}_{\mathrm{v}} / \mathrm{F}_{\mathrm{m}}\right)$.

Statistical analysis: All data are expressed as the mean \pm standard deviation $(\mathrm{M} \pm \mathrm{SD})$ of five replicates $(n=5)$. Group mean ranks were compared using the nonparametric Mann-Whitney's $U$ test with a significance level of $p<0.05$. Correlations between parameters were evaluated using Spearman's rank correlation coefficient $(\rho)$. All statistical analyses were performed in the Statistica 7.0 software package (StatSoft Inc., Tulsa, USA, 2004).

lower $\mathrm{pH}$ values increased the pool of available $\mathrm{Zn}$, which represents between 53 and $69 \%$ of the total $\mathrm{Zn}$ content in soils under the different $\mathrm{Zn}$ treatments (Table 1).

All plants grown in $\mathrm{Zn}$-treated soils had significantly 
higher amounts of $\mathrm{Zn}$ in comparison with the control plants (Fig. 1A). The concentrations of $\mathrm{Zn}$ in roots, stems, and leaves largely corresponded to its amount in the associated soil, and were as follows: control plants $(56.4,56.0$, and $15.1 \mathrm{mg} \mathrm{kg}^{-1}$, respectively), $\mathrm{T}_{250}(337.2,277.3$, and $185.5 \mathrm{mg} \mathrm{kg}{ }^{-1}$, respectively), $\mathrm{T}_{500}(505.3,528.2$, and $177.3 \mathrm{mg} \mathrm{kg}^{-1}$, respectively), and $\mathrm{T}_{1,000}(704.0,424.0$, and $273.2 \mathrm{mg} \mathrm{kg}{ }^{-1}$, respectively) (Fig. 1A). Also, the concentrations of $\mathrm{Zn}$ in rhizomes of plants of the $\mathrm{T}_{250}$ $\left(128.5 \mathrm{mg} \mathrm{kg}^{-1}\right), \mathrm{T}_{500}\left(155.1 \mathrm{mg} \mathrm{kg}^{-1}\right)$, and $\mathrm{T}_{1,000}(338.2 \mathrm{mg}$ $\mathrm{kg}^{-1}$ ) were significantly higher than in rhizomes of the control plants (26.0 $\left.\mathrm{mg} \mathrm{kg}^{-1}\right)$ (Fig. 1A).

The control plants showed statistically significantly lower amounts of $\mathrm{Zn}$ in all plant organs compared to all $\mathrm{Zn}$-treated plants. Among Zn-treated plants, there were significant differences in the concentrations of $\mathrm{Zn}$ in the roots (between $T_{250}$ and $T_{500}$, between $T_{250}$ and $T_{1,000}$, and between $T_{500}$ and $T_{1,000}$ ) and leaves (between $T_{250}$ and $\mathrm{T}_{1,000}$, and between $\mathrm{T}_{500}$ and $\mathrm{T}_{1,000}$ ) (Fig. $1 A$ ). The bioconcentration factor (BCF) $(0.70-1.11)$ and bioaccumulation factor (BAF) (0.23-0.61) for $\mathrm{Zn}$ were lower than 1 in all plants, except those of the $\mathrm{T}_{250}$, where BCF slightly exceeded 1 (Fig. $1 B$ ). The translocation factor $(\mathrm{TF})$ for $\mathrm{Zn}$ was lower than $1(0.27-0.55)$ in all $M . \times$ giganteus plants grown in experimental soils (Fig. 1B). There were no statistically significant differences of BCF values between control and Zn-treated plants (Fig. $1 B$ ), whereas plants in
$\mathrm{T}_{1,000}$ had significantly lower BCF than in $\mathrm{T}_{250}$ and $\mathrm{T}_{500}$ (Fig. 1B). Plants in $\mathrm{T}_{250}$ showed higher BAF compared with the control, $\mathrm{T}_{500}$, and $\mathrm{T}_{1,000}$, whereas there were no statistically significant differences between control and plants in $\mathrm{T}_{500}$ and $\mathrm{T}_{1,000}$ (Fig. $1 B$ ). In this study, $\mathrm{T}_{250}$ and $\mathrm{T}_{1,000}$ plants had higher TF values than that in the control plants. At the same time, there were no significant differences of $\mathrm{TF}$ values between $\mathrm{Zn}$-treated plants (between $T_{250}$ and $T_{500}$, between $T_{250}$ and $T_{1,000}$, and between $\mathrm{T}_{500}$ and $\mathrm{T}_{1,000}$ ) (Fig. $1 B$ ).

Photosynthetic pigments: The amounts of Chl $a$, Chl $b$, $\mathrm{Chl}(a+b)$, and Car, together with values of the Chl $a / b$ ratio are shown in Table 2. Differences in the content of Chl $a$, Chl $(a+b)$, and Car between the control and $\mathrm{Zn}$ treated plants were not statistically significant. However, significant differences of $\mathrm{Chl} b$ content were noted between control and $\mathrm{T}_{500}$ plants, and between control plants and those of the $T_{1,000}$. Furthermore, significant differences in values of the $\mathrm{Chl} a / b$ ratio were found between $\mathrm{T}_{250}$ and $\mathrm{T}_{500}$, and between $\mathrm{T}_{250}$ and $\mathrm{T}_{1,000}$.

After three months of treatment, Zn-treated plants showed visible signs of $\mathrm{Zn}$ toxicity in the form of chlorotic spots on the leaf lamina, observable only in mature leaves, and in $T_{1,000}$ plants even in the form of necrotic damage present along the leaf margins in the oldest leaves (Fig. 2A,B).

Table 1. The $\mathrm{pH}$ values and concentrations of total and available $\mathrm{Zn}$ in the control soil and soil treated with different concentrations of $\mathrm{Zn}$. Mann-Whitney $U$ test. Statistically significantly different values are separated by different letters for each column.

\begin{tabular}{llllll}
\hline Treatment & pHн2О & pHкCl & $\begin{array}{l}\text { Total Zn } \\
{\left[\mathrm{mg} \mathrm{kg}^{-1}(\mathrm{DM})\right]}\end{array}$ & $\begin{array}{l}\text { Available Zn } \\
{\left[\mathrm{mg} \mathrm{kg}^{-1}(\mathrm{DM})\right]}\end{array}$ & $\begin{array}{l}\text { Available pool of Zn } \\
\text { in the total Zn [\%] }\end{array}$ \\
\hline Control & 6.5 & 5.4 & $64 \pm 9^{\mathrm{a}}$ & $9.3 \pm 7.8^{\mathrm{a}}$ & 15 \\
$\mathrm{~T}_{250}$ & 6.6 & 5.8 & $305 \pm 1^{\mathrm{b}}$ & $161 \pm 20^{\mathrm{b}}$ & 53 \\
$\mathrm{~T}_{500}$ & 6.4 & 5.5 & $528 \pm 28^{\mathrm{c}}$ & $366 \pm 14^{\mathrm{c}}$ & 69 \\
$\mathrm{~T}_{1,000}$ & 6.1 & 5.5 & $1,015 \pm 82^{\mathrm{d}}$ & $678 \pm 23^{\mathrm{d}}$ & 67 \\
\hline
\end{tabular}
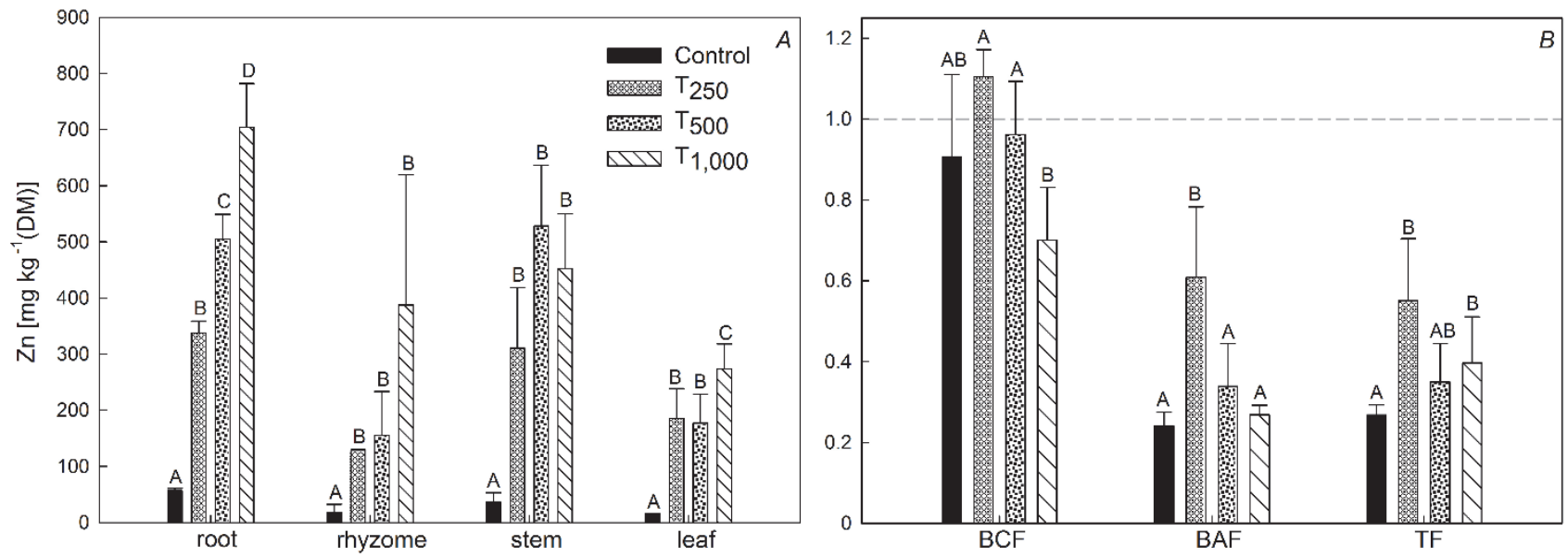

Fig. 1. Concentrations of $\mathrm{Zn}$ in different plant organs in Miscanthus $\times$ giganteus grown on different $\mathrm{Zn}$ concentrations $(A)$; bioconcentration factor (BCF), bioaccumulation factor (BAF), and translocation factor (TF) for zinc $(B)$. Statistically significantly different values are separated by different letters within each group of bars. 
Table 2. Content of chlorophyll $a(\mathrm{Chl} a)$, chlorophyll $b(\mathrm{Chl} b)$, and total carotenoids (Car) in leaves of Miscanthus $\times$ giganteus grown in the control soil and soils treated with different concentrations of Zn. Mann-Whitney $U$ test. Statistically significantly different values are separated by different letters for each column.

\begin{tabular}{llllll}
\hline Treatment & $\begin{array}{l}\text { Chl }(a+b) \\
{\left[\mathrm{mg} \mathrm{g}^{-1}(\mathrm{DM})\right]}\end{array}$ & $\begin{array}{l}\mathrm{Chl} a \\
{\left[\mathrm{mg} \mathrm{g}^{-1}(\mathrm{DM})\right]}\end{array}$ & $\begin{array}{l}\mathrm{Chl} b \\
{\left[\mathrm{mg} \mathrm{g}^{-1}(\mathrm{DM})\right]}\end{array}$ & $\begin{array}{l}\text { Chl } a / b \\
\text { Cor }\end{array}$ & $\begin{array}{l}\text { Car } \\
{\left[\mathrm{mg} \mathrm{g}^{-1}(\mathrm{DM})\right]}\end{array}$ \\
\hline Control & $4.14 \pm 1.70^{\mathrm{a}}$ & $3.08 \pm 0.50^{\mathrm{a}}$ & $1.06 \pm 0.15^{\mathrm{a}}$ & $2.91 \pm 0.19^{\mathrm{a}}$ & $0.85 \pm 0.19^{\mathrm{a}}$ \\
$\mathrm{T}_{250}$ & $4.09 \pm 1.63^{\mathrm{a}}$ & $3.06 \pm 0.65^{\mathrm{a}}$ & $1.03 \pm 0.03^{\mathrm{a}}$ & $2.97 \pm 0.39^{\mathrm{ab}}$ & $0.86 \pm 0.59^{\mathrm{a}}$ \\
$\mathrm{T}_{500}$ & $3.53 \pm 1.48^{\mathrm{a}}$ & $2.77 \pm 0.28^{\mathrm{a}}$ & $0.76 \pm 0.05^{\mathrm{b}}$ & $3.64 \pm 0.28^{\mathrm{b}}$ & $0.80 \pm 0.28^{\mathrm{a}}$ \\
$\mathrm{T}_{1,000}$ & $3.23 \pm 1.28^{\mathrm{a}}$ & $2.52 \pm 0.57^{\mathrm{a}}$ & $0.71 \pm 0.11^{\mathrm{b}}$ & $3.55 \pm 0.28^{\mathrm{b}}$ & $0.71 \pm 0.28^{\mathrm{a}}$ \\
\hline
\end{tabular}

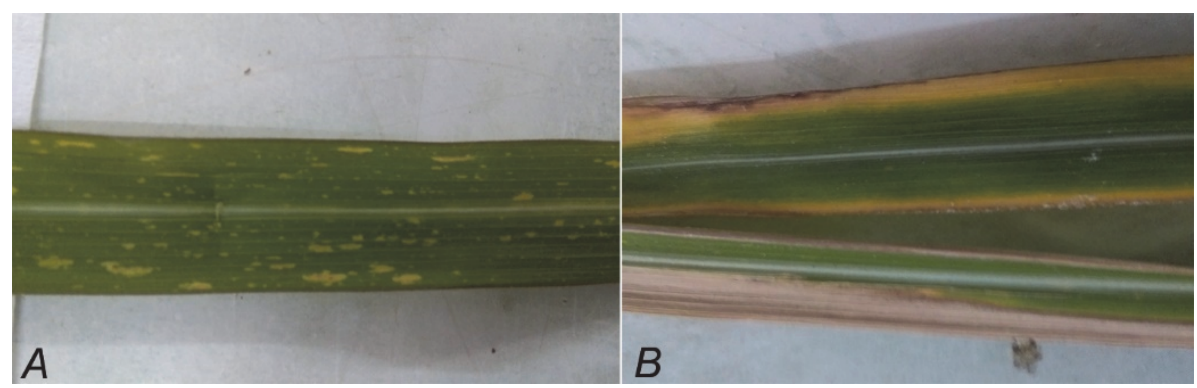

Fig. 2. Visible damage on leaves caused by $\mathrm{Zn}$ excess: chlorotic spots on mature leaf $(A)$ and dry margins on old leaves $(B)$.

Gas exchange and Chl fluorescence: Although in all plants $P_{\mathrm{N}}$ was saturated at a relatively high PPFD of

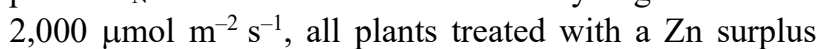
showed almost two-fold lower photosynthetic activity at maximum PPFD compared to the control plants (Fig. 3A). Increase in $C_{\mathrm{i}}$ under constant light intensity (PPFD of $1,500 \mu \mathrm{mol} \mathrm{m} \mathrm{m}^{-2} \mathrm{~s}^{-1}$ ) resulted in a uniform increase of $P_{\mathrm{N}}$ in both the control and all Zn-treated plants, with photosynthetic activity decreasing in proportion to increase in the concentration of applied $\mathrm{Zn}$ (Fig. $3 B$ ).

The parameters $P_{\mathrm{N}}, E, g_{\mathrm{s}}$, and $C_{\mathrm{i}}$ were significantly lower in all $\mathrm{Zn}$-treated plants compared to the control ones (Table 3$)$. Respiration $(R)$ was significantly higher in the control and $\mathrm{T}_{250}$ than that in plants treated with higher

\section{Discussion}

Frequent $\mathrm{Zn}$ contamination of surface soils originating from prolonged use of $\mathrm{Zn}$ fertilizers, input from industrial pollution, and mining activities leads to $\mathrm{Zn}$ toxicity in plants (Kabata-Pendias 2011, Martens and Smolders 2013). Plants differ in their ability to tolerate elevated concentrations of $\mathrm{Zn}$ in the soil, exhibiting different strategies of coping with excessive amounts of $\mathrm{Zn}$ that are involved in its absorption, translocation, and redistribution within the plant (Sinclair and Krämer 2012, Tsonev and Lidon 2012).

The concentrations of $\mathrm{Zn}$ applied to the soil in all treatments were higher than the mean amounts of $\mathrm{Zn}$ present in different undisturbed and agricultural soils in the world (Eriksson 2001, Takeda et al. 2004, Herselman et al. 2005, Kabata-Pendias 2011). The concentrations of soluble $\mathrm{Zn}$ in treated soils ranged from 161 to 366 and concentrations of $\mathrm{Zn}\left(\mathrm{T}_{500}, \mathrm{~T}_{1,000}\right)$. Fluorescence parameters $F_{m}, F_{v}$, and $F_{v} / F_{m}$ were significantly lower, whereas $\mathrm{F}_{0}$ was significantly higher in all $\mathrm{Zn}$-treated plants than in the control. In addition, $\mathrm{F}_{\mathrm{m}}, \mathrm{F}_{\mathrm{v}}$ and $\mathrm{F}_{\mathrm{v}} / \mathrm{F}_{\mathrm{m}}$ were significantly higher in $\mathrm{T}_{250}$ and $\mathrm{T}_{500}$ in comparison with $\mathrm{T}_{1,000}$.

Negative correlations were found between the amount of $\mathrm{Zn}$ in leaves and $P_{\mathrm{N}}, E, g_{\mathrm{s}}, C_{\mathrm{i}}$, fluorescence parameters $\left(\mathrm{F}_{\mathrm{m}}, \mathrm{F}_{\mathrm{v}}, \mathrm{F}_{\mathrm{v}} / \mathrm{F}_{\mathrm{m}}\right)$, and $\mathrm{Chl} b$ content. Positive correlations were found between the concentration of $\mathrm{Zn}$ in leaves and both $R$ and the Chl $a / b$ ratio (Table 4 ). Furthermore, significant correlations were found between parameters of gas exchange, Chl $a$ fluorescence, and pigment content (Table 4).

$678 \mathrm{mg} \mathrm{kg}^{-1}(\mathrm{DM})$, which were 17.2, 39.2, and 72.6 times higher than its concentration in the unpolluted control soil. As a consequence, the amounts of $\mathrm{Zn}$ in all $\mathrm{Zn}$-treated plants were significantly higher than in the control ones, and were on concentrations considered toxic to most plant species (Macnicol and Beckett 1985, Kabata-Pendias 2011). The strong positive correlation between $\mathrm{Zn}$ in plant roots and $\mathrm{Zn}$ in the soil indicates that the amounts of $\mathrm{Zn}$ in roots strongly depend on its concentration in the soil. However, the progressive decrease of BCF with increasing $\mathrm{Zn}$ concentration in the soil indicated that $M . \times$ giganteus limited absorption of $\mathrm{Zn}$ to roots at higher $\mathrm{Zn}$ concentrations in the soil. Furthermore, according to relatively low BAF and $\mathrm{TF}$ values and the mostly uniform concentration of $\mathrm{Zn}$ in leaves between treatments, the $\mathrm{Zn}$ translocation from roots to leaves was restricted. The 


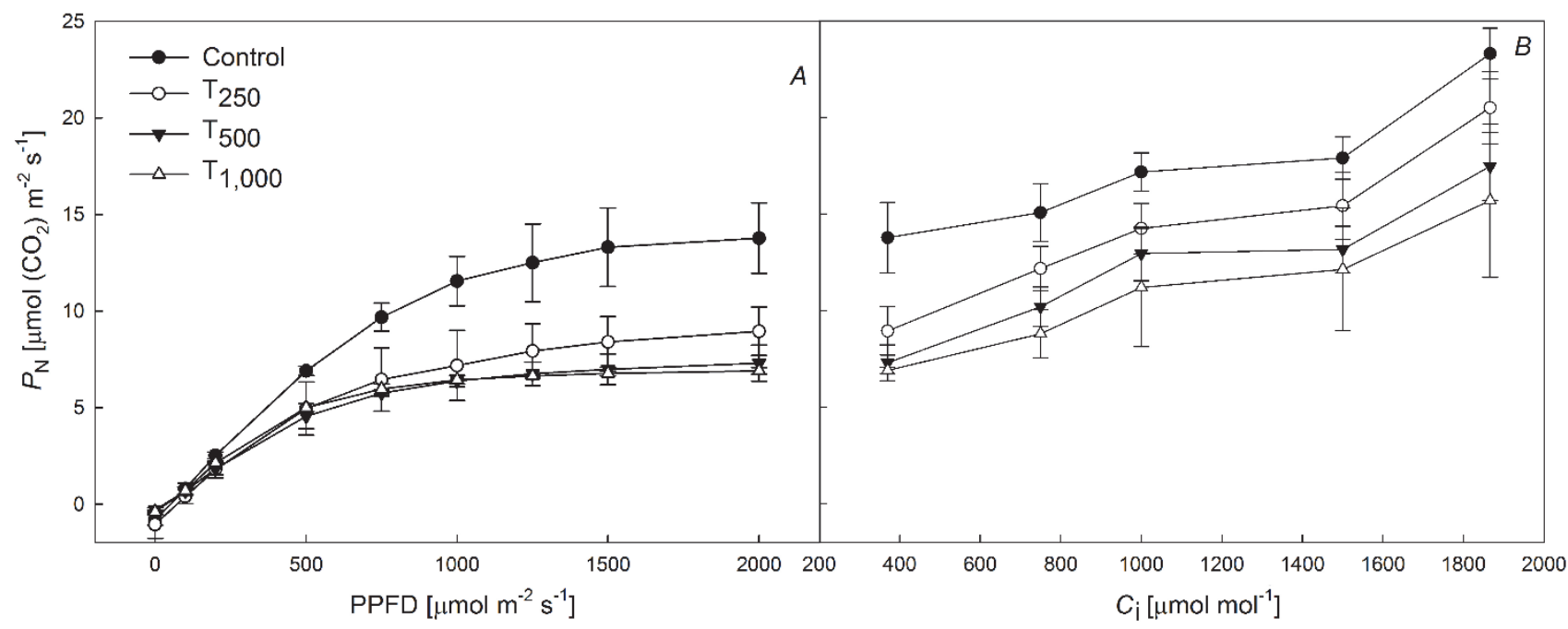

Fig. 3. Photosynthetic rate $\left(P_{\mathrm{N}}\right)$ in Miscanthus $\times$ giganteus grown on different $\mathrm{Zn}$ concentrations as a function of photosynthetic photon flux density (PPFD) (light-response curves, $\left.P_{\mathrm{N}} / \mathrm{PPFD}\right)(A)$ and of increasing intercellular $\mathrm{CO}_{2}$ concentrations $\left(C_{\mathrm{i}}\right)\left(P_{\mathrm{N}}\right.$ responses to high $\left.C_{\mathrm{i}}, B\right)$.

Table 3. Parameters of gas exchange and Chl fluorescence in Miscanthus $\times$ giganteus grown in the control soil and soils treated with different concentrations of $\mathrm{Zn}\left(P_{\mathrm{N}}-\right.$ net photosynthetic rate; $R$ - respiration; $E$ - transpiration rate; $g_{\mathrm{s}}$ - stomatal conductance; $C_{\mathrm{i}}-$ leaf intercellular $\mathrm{CO}_{2}$ concentration, $\mathrm{F}_{0}$ - minimal fluorescence yield of the dark-adapted state; $\mathrm{F}_{\mathrm{m}}$ - maximal fluorescence yield of the darkadapted state; $\mathrm{F}_{\mathrm{v}}$ - variable fluorescence; $\mathrm{F}_{\mathrm{v}} / \mathrm{F}_{\mathrm{m}}$ maximal quantum yield of PSII photochemistry). Mann-Whitney $U$ test. Statistically significantly different values are separated by different letters for each column.

\begin{tabular}{lcccc}
\hline Parameter & \multicolumn{1}{l}{ Control } & \multicolumn{1}{c}{$\mathrm{T}_{250}$} & \multicolumn{1}{c}{$\mathrm{T}_{500}$} & \multicolumn{1}{c}{$\mathrm{T}_{1,000}$} \\
\hline$P_{\mathrm{N}}\left[\mu \mathrm{mol} \mathrm{m} \mathrm{m}^{-2} \mathrm{~s}^{-1}\right]$ & $11.1 \pm 1.18^{\mathrm{a}}$ & $6.8 \pm 2.02^{\mathrm{b}}$ & $6.4 \pm 0.36^{\mathrm{b}}$ & $6.4 \pm 0.21^{\mathrm{b}}$ \\
$R\left[\mu \mathrm{mol}\left(\mathrm{CO}_{2}\right) \mathrm{m}^{-2} \mathrm{~s}^{-1}\right]$ & $-1.2 \pm 0.00^{\mathrm{a}}$ & $-1.3 \pm 0.62^{\mathrm{a}}$ & $-0.33 \pm 0.11^{\mathrm{b}}$ & $-0.40 \pm 0.10^{\mathrm{b}}$ \\
$E\left[\mathrm{mmol}\left(\mathrm{H}_{2} \mathrm{O}\right) \mathrm{m}^{-2} \mathrm{~s}^{-1}\right]$ & $1.7 \pm 0.30^{\mathrm{a}}$ & $1.06 \pm 0.25^{\mathrm{b}}$ & $0.97 \pm 0.29^{\mathrm{b}}$ & $0.87 \pm 0.58^{\mathrm{b}}$ \\
$g_{\mathrm{s}}\left[\mathrm{mmol}\left(\mathrm{H}_{2} \mathrm{O}\right) \mathrm{m}^{-2} \mathrm{~s}^{-1}\right]$ & $101.0 \pm 19.44^{\mathrm{a}}$ & $53.0 \pm 13.75^{\mathrm{b}}$ & $50.3 \pm 12.86^{\mathrm{b}}$ & $45.0 \pm 3.6^{\mathrm{b}}$ \\
$C_{\mathrm{i}}\left[\mu \mathrm{mol}\left(\mathrm{CO}_{2}\right) \mathrm{mol}^{-1}\right]$ & $148.0 \pm 0.00^{\mathrm{a}}$ & $143.7 \pm 14.57^{\mathrm{a}}$ & $141.7 \pm 37.58^{\mathrm{a}}$ & $112.0 \pm 22.07^{\mathrm{b}}$ \\
$\mathrm{F}_{0}$ & $498.6 \pm 30.00^{\mathrm{a}}$ & $562.0 \pm 4.58^{\mathrm{b}}$ & $517.7 \pm 36.0^{\mathrm{a}}$ & $534.3 \pm 60.54^{\mathrm{ab}}$ \\
$\mathrm{F}_{\mathrm{m}}$ & $2386.3 \pm 143.51^{\mathrm{a}}$ & $2091.7 \pm 52.59^{\mathrm{b}}$ & $2043.3 \pm 137.71^{\mathrm{bc}}$ & $1854.7 \pm 170.88^{\mathrm{c}}$ \\
$\mathrm{F}_{\mathrm{v}}$ & $1887.6 \pm 122.68^{\mathrm{a}}$ & $1529.7 \pm 55.08^{\mathrm{b}}$ & $1525.7 \pm 103.5^{\mathrm{bc}}$ & $1317.3 \pm 219.15^{\mathrm{c}}$ \\
$\mathrm{F}_{\mathrm{v}} / \mathrm{F}_{\mathrm{m}}$ & $0.790 \pm 0.01^{\mathrm{a}}$ & $0.736 \pm 0.01^{\mathrm{b}}$ & $0.746 \pm 0.00^{\mathrm{b}}$ & $0.704 \pm 0.06^{\mathrm{c}}$ \\
\hline
\end{tabular}

concentrations of $\mathrm{Zn}$ in the rhizome were 2-3 times lower than that in the roots, indicating that most of the $\mathrm{Zn}$ was retained within the roots or was translocated to the stem. On the basis of the concentrations of $\mathrm{Zn}$ in its organs, it can be asserted that $M . \times$ giganteus represents an excluder plant species suitable for $\mathrm{Zn}$ phytostabilization. This is in accordance with previously reported low accumulation of $\mathrm{Zn}, \mathrm{Cu}, \mathrm{Ni}, \mathrm{Cd}, \mathrm{Pb}, \mathrm{As}$, and $\mathrm{Sb}$ in aerial biomass of $M . \times$ giganteus (Fernando and Oliviera 2004, Wanat et al. 2013, Korzeniowska and Stanislawska-Glubiak 2015, Kocoń and Jurga 2017).

Although the $\mathrm{Zn}$ concentrations detected in leaves were in the range considered as toxic to most plant species (Macnicol and Beckett 1985, Kabata-Pendias 2011), signs of $\mathrm{Zn}$ toxicity were not visible in young leaves, but were observed only in the oldest leaves in the form of small chlorotic areas on the leaf lamina and necrotic leaf margins. The detected leaf damage indicates that over time
$\mathrm{Zn}$ was concentrated in older leaves, where it induced their senescence, as it was previously shown in several different plant species (Prasad 2004).

Regarding pigments, high contents of $\mathrm{Zn}$ in $M . \times$ giganteus leaves resulted in the decline of $\mathrm{Chl} b$ content $(\rho=-0.5594)$ and a consequent increase of the Chl $a / b$ ratio $(\rho=0.6014)$, pointing to higher sensitivity of $\mathrm{Chl} b$ to Zn stress compared to Chl $a$ and Car. Similarly, Li et al. (2014) observed that the amount of Chl $(a+b)$ in leaves of Miscanthus sacchariflorus and Arundo donax did not change significantly under the influence of different concentrations of $\mathrm{Zn}$ in the soil [250, 500, 1,000; and $\left.2,000 \mathrm{mg} \mathrm{kg}{ }^{-1}(\mathrm{DM})\right]$. Since $\mathrm{Chl} b$ builds the lightharvesting protein complex (LHCP) (Lambers et al. 1998), decreased content of $\mathrm{Chl} b$ and high values of the $\mathrm{Chl} a / b$ ratio in Zn-stressed $M . \times$ giganteus leaves indicate sensitivity of the LHCP. However, the insignificant changes in the content of Chl $a$ and Car in Zn-stressed plants suggest 


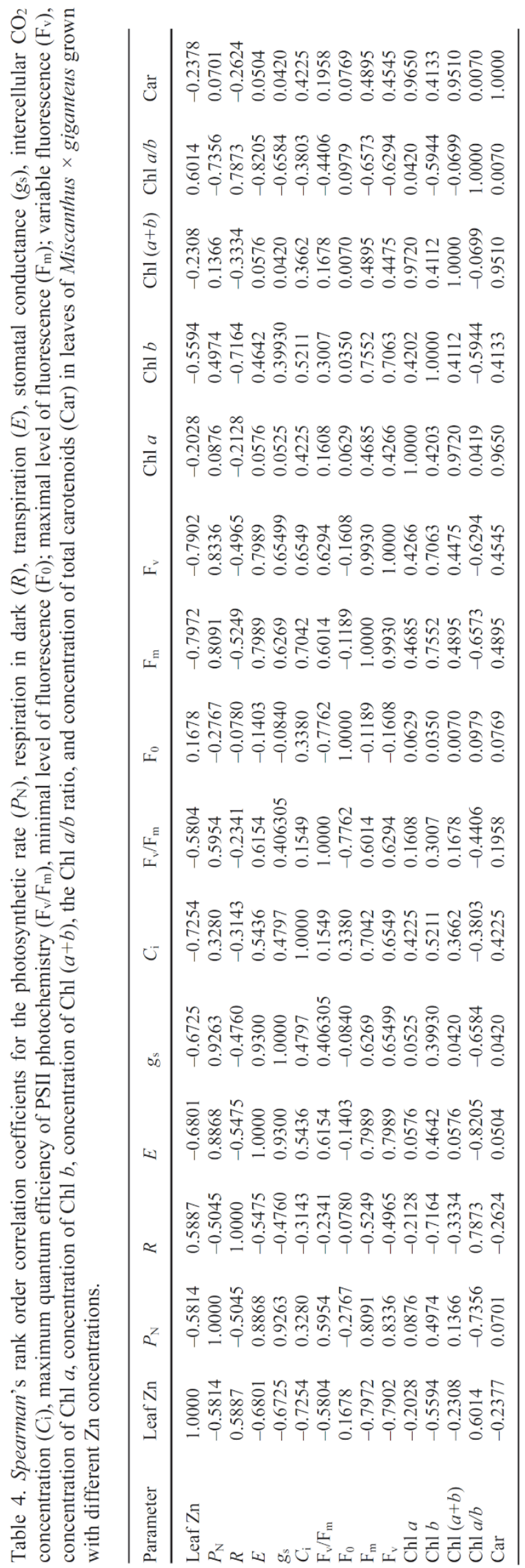

low sensitivity of photochemical reaction centres and high efficiency of Car in protecting the photosynthetic system from photoinhibition (Farage et al. 2006).

At maximum light intensity of $2,000 \mu \mathrm{mol}($ photon) $\mathrm{m}^{-2} \mathrm{~s}^{-1}$, the control plants had 2-3 times higher rates of photosynthesis than the Zn-treated plants, confirming that $P_{\mathrm{N}}$ is highly sensitive to elevated $\mathrm{Zn}$ concentrations. The presence of excessive $\mathrm{Zn}$ negatively affected all measured parameters of leaf gas exchange; it caused decrease of $E$ $(\rho=-0.6801), g_{\mathrm{s}}(\rho=-0.6725), C_{\mathrm{i}}(\rho=-0.7254)$, and $P_{\mathrm{N}}$ $(\rho=-0.5814)$. Similarly, decrease of both $P_{\mathrm{N}}$ and $g_{\mathrm{s}}$ were reported in $M . \times$ giganteus leaves exposed to $\mathrm{As}, \mathrm{Pb}$, and $\mathrm{Sb}$ (Wanat et al. 2013) and in three different Miscanthus species exposed to $\mathrm{Cd}$ (Guo et al. 2016). In Zn-stressed plants, reduced values of $g_{\mathrm{s}}$ decreased $C_{\mathrm{i}}(\rho=0.4797)$ and $P_{\mathrm{N}}(\rho=0.9263)$, indicating the existence of stomatal limitation of photosynthesis. Furthermore, Sagardoy et al. $(2009,2010)$ found that stomatal and mesophyll conductances to $\mathrm{CO}_{2}$ are the main limitations to photosynthesis in sugar beet (Beta vulgaris) plants grown in the presence of excess $\mathrm{Zn}$. This negative effect of elevated $\mathrm{Zn}$ on $g_{\mathrm{s}}$ can be attributed to its influence on stomatal movement through the inhibition of water channels, as shown by Yang et al. (2004), and to reduction of $\mathrm{K}^{+}$uptake (Tsalandzono et al. 1994, Vaillant et al. 2005). According to Van Assche and Clijsters (1986), high Zn concentrations can also decrease Rubisco activity, since $\mathrm{Zn}$ can replace $\mathrm{Mg}$ in the enzyme's structure.

The values of $\mathrm{F}_{\mathrm{v}} / \mathrm{F}_{\mathrm{m}}$ detected in the control plants were in the range that is considered optimal for plants $(0.750$ 0.850) (Björkman and Demmig 1987). In $\mathrm{T}_{250}$ and $\mathrm{T}_{500}$ plants its values were at the lower optimum level, while those of the $T_{1,000}$ plants it was slightly below the optimal range. Decline in values of $\mathrm{F}_{\mathrm{v}} / \mathrm{F}_{\mathrm{m}}$ pointed to the photoinhibiton of PSII and indicated a moderate negative impact of $\mathrm{Zn}$ concentrations on photosynthetic activity in $M . \times$ giganteus. The presented findings are in accordance with results obtained on $M . \times$ giganteus treated with high concentrations of $\mathrm{As}, \mathrm{Pb}$, and $\mathrm{Sb}$ (Wanat et al. 2013), and Lolium perenne (Bonnet et al. 2000), Pisum sativum (Szalontai et al. 1999), and Datura sp. (Vaillant et al. 2005 ) treated with excess $\mathrm{Zn}$. In the present study, changes in the $F_{v} / F_{m}$ ratio in $Z n$-stressed plants $(\rho=-0.5804)$ occurred due to simultaneous increase in $F_{0}(\rho=-0.7762)$, decrease in $F_{m}(\rho=0.6014)$, and decrease in $F_{v}$ $(\rho=0.6294)$, which is consistent with results previously obtained on the aforementioned plant species (Szalontai et al. 1999, Vaillant et al. 2005) and for M. × giganteus grown on soil contaminated with $\mathrm{Zn}, \mathrm{Pb}$, and $\mathrm{Cd}$ (Pogrzeba et al. 2017). The decrease of $F_{m}$ may indicate that the $Q_{A}$ reduction rate is high and electron transfer from quinone acceptors $\left(\mathrm{Q}_{\mathrm{A}}\right)$ to the next carrier $\left(\mathrm{Q}_{\mathrm{B}}\right)$ is slowed (Baker and Rosenqvist 2004). The smaller amount of $\mathrm{Chl} b$ in Zn-treated $M . \times$ giganteus suggests dissociation of the LHCPII complex from the PSII core, which can be linked with the observed low $F_{m}(\rho=0.7552)$ and $F_{v}(\rho=0.7063)$ values. Similar results were obtained by other authors, who 
recorded a small decrease of $F_{v} / F_{m}$ in the presence of a $\mathrm{Zn}$ surplus in plants (Dhir et al. 2008, Sagardoy et al. 2010). In the present study, positive correlations of $\mathrm{Chl} a$ content and $\mathrm{Chl}(a+b)$ content with the value of $\mathrm{F}_{\mathrm{m}}(\rho=0.4685$ and $\rho=0.4895$, respectively) and of Car content with Chl $a$ content $(\rho=0.9650), \mathrm{Chl}(a+b)$ content $(\rho=0.9510)$, the value of $F_{m}(\rho=0.4895)$, and that of $F_{v}(\rho=0.4545)$ pointed to good ability of $M$. $\times$ giganteus to maintain high photosynthetic efficiency under conditions of $\mathrm{Zn}$ excess.

The moderate decrease of $\mathrm{F}_{\mathrm{v}} / \mathrm{F}_{\mathrm{m}}$ in $\mathrm{Zn}$-stressed $M . \times$ giganteus indicates: (1) the presence of specific mechanisms for effective immobilization of $\mathrm{Zn}$ within leaves; and (2) high efficiency of Car and a number of antioxidant enzymes in protecting the photosynthetic system from oxidative destruction (Bonnet et al. 2000, Sun et al. 2005, Farage et al. 2006, Sagardoy et al. 2010, Lu 2011, Nadgórska-Socha et al. 2013).

Conclusions: The concentrations of $\mathrm{Zn}$ in $M . \times$ giganteus plants followed those of total and available $\mathrm{Zn}$ in the

\section{References}

Arnon D.I.: Copper enzymes in isolated chloroplasts: polyphenoloxidases in Beta vulgaris. - Plant Physiol. 24: 1-15, 1949.

Baker A.J.M.: Accumulators and excluders-strategies in the response of plants to heavy metals. - J. Plant Nutr. 3: 643-654, 1981.

Baker N.R., Rosenqvist E.: Applications of chlorophyll fluorescence can improve crop production strategies: an examination of future possibilities. - J. Exp. Bot. 55: 1607-1621, 2004.

Bang J., Kamala-Kannan S., Lee K.J. et al.: Phytoremediation of heavy metals in contaminated water and soil using Miscanthus $s p$. Goedae-Uksae 1. - Int. J. Phytoremediat. 17: 515-20, 2015.

Beale C.V., Bint D.A., Long S.P.: Leaf photosynthesis in the $\mathrm{C}_{4}-$ grass Miscanthus $x$ giganteus, growing in the cool temperate climate of southern England. - J. Exp. Bot. 47: 267-273, 1996.

Björkman O., Demmig B.: Photon yield of $\mathrm{O}_{2}$ evolution and chlorophyll fluorescence at $77 \mathrm{k}$ among vascular plants of diverse origins. - Planta 170: 489-504, 1987.

Bonnet M., Camares O., Veisseire P.: Effects of zinc and influence of Acremonium lolii on growth parameters, chlorophyll $a$ fluorescence and antioxidant enzyme activities of ryegrass (Lolium prenne L. cv. Apollo). - J. Exp. Bot. 51: 945-953, 2000.

Bremner J.M.: Nitrogen total. - In: Sparks D.L. (ed.): Methods of Soil Analysis, Part 3: Chemical Methods. Pp. 1085-1122. SSSA Book Series 5. Soil Science Society of America, Madison 1996.

Clifton-Brown J.C., Lewandowski I., Bangerth F. et al.: Comparative responses to water stress in stay-green, rapid- and slow senecing genotypes of the biomass crop, Miscanthus. - New Phytol. 154: 335-345, 2002.

Dhir B., Sharmila P., Pardha Saradhi P.P.: Photosynthetic performance of Salvinia natans exposed to chromium and zinc rich wastewater. - Braz. J. Plant Physiol. 20: 61-70, 2008.

Dželetović Ž., Mihailović N., Živanović I.: Prospects of using bioenergy crop Miscanthus $\times$ giganteus in Serbia. - In: Méndez-Vilas A. (ed.): Materials and Processes for Energy: Communicating Current Research and Technological associated soils, indicating that the plant was unable to prevent uptake of $\mathrm{Zn}$, but accumulated it in varying amounts in different plant organs. However, the plants restricted their uptake of $\mathrm{Zn}$, especially at higher $\mathrm{Zn}$ concentrations in the soil, which resulted in lower BCF, $\mathrm{BAF}$, and TF values in the presence of higher amounts of applied $\mathrm{Zn}$. Considering that only the concentrations of $\mathrm{Zn}$ in the underground organs of the plants reflected external $\mathrm{Zn}$ concentrations, whereas the $\mathrm{Zn}$ concentration in their aboveground organs remained constant over the experimental range of soil concentrations, we can conclude that $M$. $\times$ giganteus is a $\mathrm{Zn}$ excluder plant species. Excess $\mathrm{Zn}$ induced visible leaf damage in the form of chlorosis and necrosis only in the oldest leaves, indicating $\mathrm{Zn}$ accumulation over time. Despite a moderate negative effect of $\mathrm{Zn}$ surplus on gas exchange and stomatal conductance limitation of photosynthesis, $M . \times$ giganteus exhibited a high photosynthetic capacity in the presence of several excessive concentrations of $\mathrm{Zn}$, indicating its high $\mathrm{Zn}$ tolerance and ability to grow on $\mathrm{Zn}$-contaminated soils.

Developments. Pp. 360-370. Formatex Research Center, Badajoz 2013.

Egner H., Riehm H., Domingo W.R.: [Studies on the chemical soil analysis as a basis for the assessment of nutrient status of the soil, II: chemical extractions metods to phosphorus and potassium determination.]. - Kungliga Lantbrukshügskolans Annaler 26: 199-215, 1960. [In German]

Eriksson J.E.: Concentrations of 61 Trace Elements in Sewage Sludge, Farmyard Manure, Mineral Fertilizers, Precipitation and in Oil and Crops. Pp. 69. Swedish EPA, Stockholm 2001.

FAO (Food and Agriculture Organization): Guidelines: Land Evaluation for Rainfed Agriculture. Soils Bulletin No 52. Pp. 237. FAO, Rome 1983.

Farage P.K., Blowers D., Long S.P. et al.: Low growth temperatures modify the efficiency of light use by photosystem II for $\mathrm{CO}_{2}$ assimilation in leaves of two chilling-tolerant C-4 species, Cyperus longus L. and Miscanthus $\times$ giganteus. - Plant Cell Environ. 29: 720-728, 2006.

Fernando A.L., Oliviera J.F.S.: Phytoremediation by Miscanthus $x$ giganteus of soils contaminated with heavy metals. - In: Gaballah I. (ed.): REWAS' 04-Global Symposium on Recycling, Waste Treatment and Clean Technology. Pp. 24192427. Minerals, Metals \& Materials Society, Madrid 2004.

Figala J., Vranová V., Rejšek K. et al.: Giant Miscanthus (Miscanthus $\times$ giganteus Greef et Deu.) - a promising plant for soil remediation: a minireview. - Acta Univ. Agric. Silvic. Mendelianae Brun. 63: 2241-2246, 2015.

Firmin S., Labidi S., Fontaine J. et al.: Arbuscular mycorrhizal fungal inoculation protects Miscanthus $x$ giganteus against trace element toxicity in a highly metal-contaminated site. Sci. Total Environ. 527-528: 91-99, 2015.

Fonteyne S., Lootens P., Muylle H. et al.: Chilling tolerance and early vigour-related characteristics evaluated in two Miscanthus genotypes. - Photosynthetica 54: 295-306, 2016.

Gajić G., Djurdjević L., Kostić O. et al:: Assessment of phytoremediation potential and an adaptive response of Festuca rubra L., sown on fly ash deposits: Native grass has a 
pivotal role in ecorestoration management. - Ecol. Eng. 93: 250-261, 2016.

Głowacka K., Jørgensen U., Kjeldsen J.B. et al.: Can the exceptional chilling tolerance of $\mathrm{C}_{4}$ photosynthesis found in Miscanthus $x$ giganteus be exceeded? Screening of a novel Miscanthus Japanese germplasm collection. - Ann. Bot.London 115: 981-990, 2015.

Guo H., Hong C., Chen X. et al.: Different growth and physiological responses to cadmium of the three Miscanthus species. - PLoS ONE 11: e0153475, 2016.

Herselman J.E., Steyn C.E., Fey M.V.: Baseline concentration of $\mathrm{Cd}, \mathrm{Co}, \mathrm{Cr}, \mathrm{Cu}, \mathrm{Pb}, \mathrm{Ni}$ and $\mathrm{Zn}$ in surface soils of South Africa. - S. Afr. J. Sci. 101: 509-512, 2005.

Hiscox J.D., Israelstam G.F.: A method for the extraction of chlorophyll from leaf tissue without maceration. - Can. J. Bot. 57: 1332-1334, 1979.

Ings J., Mur L.A.J., Robson R.R.H. et al.: Physiological and growth responses to water deficit in the bioenergy crop Miscanthus $x$ giganteus. - Front. Plant Sci. 4: 468, 2013.

Jiao X., Kørup K., Andersen M.N. et al.: Low-temperature leaf photosynthesis of a Miscanthus germplasm collection correlates positively to shoot growth rate and specific leaf area. - Ann. Bot.-London 117: 1229-1239, 2016.

Jiao X., Kørup K., Andersen M.N. et al:: Can miscanthus $\mathrm{C}_{4}$ photosynthesis compete with festulolium $\mathrm{C}_{3}$ photosynthesis in a temperate climate? - GCB Bioenergy 9: 18-30, 2017.

Kabata-Pendias A.: Trace Elements in Soils and Plants. $4^{\text {th }}$ ed. Pp. 505. Taylor and Francis, Boca Raton 2011.

Kloke A., Sauerbeck D.R., Vetter H.: The contamination of plants and soils with heavy metals and the transport of metals in terrestrial food chains. - In: Nriagu J.O., Andreae M.O. (ed.): Changing Metal Cycles and Human Health. Report of the Dahlem Workshop on Changing Metal Cycles and Human Health Berlin. Pp. 446. Springer-Verlag GmbH, Berlin 1983.

Korzeniowska J., Stanislawska-Glubiak E.: Phytoremediation potential of Miscanthus $x$ giganteus and Spartina pectinata in soil contaminated with heavy metals. - Environ. Sci. Polutt. R. 22: 11648-11657, 2015.

Kocoń A., Jurga B.: The evaluation of growth and phytoextraction potential of Miscanthus x giganteus and Sida hermafrodita on soil contaminated simultaneously with $\mathrm{Cd}$, $\mathrm{Cu}, \mathrm{Ni}, \mathrm{Pb}$, and Zn. - Environ. Sci. Polutt. R. 24: 4990-5000, 2017.

Lambers H., Chapin F.S., Pons T.L.: Plant Physiological Ecology. Pp. 540. Springer-Verlag, New York 1998.

Li C., Xiao B., Wang Q.H. et al.: Phytoremediation of $\mathrm{Zn}$-and Cr-contaminated soil using two promising energy grasses. Water Air Soil Pollut. 225: 2027, 2014.

Lu Y.: The occurrence of a thylakoid-localized small zinc finger protein in land plants. - Plant Signal. Behav. 6: 1881-1885, 2011.

Ma J.-Y., Sun W., Koteyeva N.K. et al.: Influence of light and nitrogen on the photosynthetic efficiency in the $\mathrm{C}_{4}$ plant Miscanthus x giganteus. - Photosynth. Res. 131: 1-13, 2017.

Macnicol R.D., Beckett P.H.T.: Critical tissue concentrations of potentially toxic elements. - Plant Soil 85: 107-129, 1985.

Marschner H.: Mineral Nutrition of Higher Plants, ${ }^{\text {nd }}$ Ed. Pp. 889. Academic Press Limited, London 1995.

Martens J., Smolders E. Zinc. - In: Alloway B.J. (ed.): Heavy Metals in Soils - Trace Metals and Metalloids in Soils and their Bioavailability. Series: Environmental Pollution 22. Pp. 465493. Springer, Dordrecht 2013.

McCalmont J.P., Hastings A., McNamara N.P. et al.: Environ- mental costs and benefits of growing Miscanthus for bioenergy in the UK. - GCB Bioenergy 9: 489-507, 2017.

Nadgórska-Socha A., Ptasiński B., Kita A.: Heavy metal bioaccumulation and antioxidative responses in Cardaminopsis arenosa and Plantago lanceolata leaves from metalliferous and non-metalliferous sites: a field study. - Ecotoxicology 22: 1422-1434, 2013.

Naidu S.L., Long S.P.: Potential mechanisms of low-temperature tolerance of $\mathrm{C}_{4}$ photosynthesis in Miscanthus $x$ giganteus: an in vivo analysis. - Planta_220: 145-155, 2004.

Nsanganwimana F., Pourrut B., Mench M. et al.: Suitability of Miscanthus species for managing inorganic and organic contaminated land and restoring ecosystem services. A review. - J. Environ. Manage. 143: 123-134, 2014.

Pandey V.C., Bajpai O., Singh N.: Energy crops in sustainable phytoremediation. - Renew. Sust. Energ. Rev. 54: 58-73, 2016.

Pansu M., Gautheyroy J.: Handbook of Soil Analysis. Mineralogical, Organic and Inorganic Methods. Pp. 993. Springer, Berlin 2006.

Pavel P.B., Puschenreiter M., Wenzel W.W. et al:: Aided phytostabilization using Miscanthus sinensis $\times$ giganteus on heavy metal-contaminated soils. - Sci. Total Environ. 479-480: 125-131, 2014.

Pelfrêne A, Kleckerová A, Pourrut B. et al.: Effect of Miscanthus cultivation on metal fractionation and human bioaccessibility in metal-contaminated soils: comparison between greenhouse and field experiments. - Environ. Sci. Pollut. R. Int. 22: 304354, 2015.

Pidlisnyuk V., Stefanovska T., Lewis E.E. et al.: Miscanthus as a productive biofuel crop for phytoremediation. - Crit. Rev. Plant Sci. 33: 1-19, 2014.

Pilgrim W., Hughes R.N.: Lead, cadmium, arsenic and zinc in the ecosystem surrounding a lead smelter. - Environ. Monit. Assess. 32: 1-20, 1994.

Pogrzeba M., Rusinowski S., Sitko K. et al.: Relationships between soil parameters and physiological status of Miscathus x giganteus cultivated on soil contaminated with trace elements under NPK fertilization vs. microbial inoculation. - Environ. Pollut. 225: 163-174, 2017.

Prasad M.N.V.: Heavy Metal Stress in Plants - From Biomolecules to Ecosystems. Pp. 462. Springer-Verlag, Berlin Heidelberg 2004.

Rutkowska B., Szulc W., Bomze K.: Plant availability of zinc in differentiated soil conditions. - Fresen. Environ. Bull. 22: 2542-2546, 2013.

Sagardoy R., Morales F., López-Millán A.F. et al..: Effects of zinc toxicity in sugar beet (Beta vulgaris L.) plants grown in hydroponics. - Plant Biol. 11: 339-350, 2009.

Sagardoy R., Vázquez S., Florez-Sarasa I. et al.: Stomatal and mesophyll conductances to $\mathrm{CO}_{2}$ are the main limitations to photosynthesis in sugar beet (Beta vulgaris) plants grown with excess zinc. - New Phytol. 187: 145-158, 2010.

Sinclair S.A., Krämer U.: The zinc homeostasis network of land plants. - Biochim Biophys Acta. 1823: 1553-1567, 2012.

Sun Q., Ye Z.H., Wang X.R. et al.: Increase of glutathione in mine population of Sedum alfredii: a $\mathrm{Zn}$ hyperaccumulator and $\mathrm{Pb}$ accumulator. - Phytochemistry 66: 2549-3256, 2005.

Sun W., Ubierna N., Ma J.-Y. et al.: The influence of light quality on $\mathrm{C}_{4}$ photosynthesis under steady-state conditions in Zea mays and Miscanthus $\times$ giganteus: changes in rates of photosynthesis but not the efficiency of the $\mathrm{CO}_{2}$ concentrating mechanism. Plant Cell Environ. 35: 982-993, 2012.

Sun W., Ubierna N., Ma J.-Y. et al:: The coordination of $\mathrm{C}_{4}$ 
photosynthesis and the $\mathrm{CO}_{2}$-concentrating mechanism in maize and Miscanthus $\times$ giganteus in response to transient changes in light quality. - Plant Physiol. 164: 1283-1292, 2014.

Szalontai B., Horváth L., Debreczeny M. et al.: Molecular rearrangements of thylakoids after heavy metal poisoning, as seen by Fourier transform infrared (FTIR) and electron spin resonance (ESR) spectroscopy. - Photosynth Res. 61: 241-252, 1999.

Takeda A., Kimura K., Yamasaki S.I.: Analysis of 57 elements in Japanese soils, with special reference to soil group, and agricultural use. - Geoderma 119: 291-307, 2004.

Técher D., Laval-Gilly P., Bennasroune A. et al.: An appraisal of Miscanthus $x$ giganteus cultivation for fly ash revegetation and soil restoration. - Ind. Crop. Prod. 36: 427-433, 2012.

Tsalandzono N.G., Omokolo N.D., Tita A.M.: Effect of $\mathrm{Fe}^{2+}$, $\mathrm{Mn}^{2+}, \mathrm{Zn}^{2+}$, and $\mathrm{Pb}^{2+}$ on $\mathrm{H}^{+} / \mathrm{K}^{+}$fluxes in excised Pistia stratiotes roots. - Biol. Plantarum 36: 591-597, 1994.

Tsonev T., Lidon F.J.C.: Zinc in plants - An overview. - Emir. J. Food Agr. 24: 322-333, 2012.

Tjurin I.V.: Agrochemical Methods of Soil Analysis. Pp. 75-102. Nauka, Moscow 1965.

Ubierna N., Sun W., Kramer D.M. et al.: The efficiency of $\mathrm{C}_{4}$ photosynthesis under low light conditions in Zea mays, Miscanthus $\times$ giganteus and Flaveria bidentis. - Plant Cell Environ. 36: 365-381, 2013.

USEPA Method 3051: Microwave assisted acid digestion of sediments, sludges and oils. - In: Test Methods for Evaluating
Solid Waste, SW-846. Environmental Protection Agency, Washington, DC 1998.

USEPA Method 3052: Microwave assisted acid digestion of siliceous and organically based matrices. - In: Test Methods for Evaluating Solid Waste, SW-846. Environmental Protection Agency, Washington, DC 1996.

Vaillant N., Monnet F., Hitmi A. et al.: Comparative study of responses in four Datura species to a zinc stress. Chemosphere 59: 1005-1013, 2005.

van Assche F., Clijsters H.: Inhibition of photosynthesis in Phaseoulus vugaris by treatment with toxic concentration of zinc: effect on ribulose-1,5-bisphosphate carboxylase/ oxygenase. - J. Plant Physiol. 125: 355-360, 1986.

Wanat N., Austruy A., Joussein E. et al.: Potential of Miscanthus $x$ giganteus grown on highly contaminated technosols. - J. Geochem. Explor. 126-127: 78-84, 2013.

Wellburn A.R.: The spectral determination of chlorophylls $a$ and $b$, as well as total carotenoids using various solvents with spectrophotometers of different resolution. - J. Plant Physiol. 144: 307-313, 1994.

Yang H.M., Zhang X.Y., Wang G.X.: Effects of heavy metals on stomatal movements in broad bean leaves. - Russ. J. Plant Physl+ 51: 464-468, 2004.

Zub H.W., Brancourt-Hulmel M.: Agronomic and physiological performances of different species of Miscanthus, a major energy crop. A review. - Agron. Sustain. Dev. 30: 201-214, 2010. 